\title{
TERAPI EKSISI PADA NEUROFIBROMA
}

\author{
Inneke Yulian ${ }^{\star 凶}$, Arif Widiatmoko*, Diah Prabawati Retnani*
}

\begin{abstract}
Abstrak
Neurofibroma dapat tampak sebagai nodul soliter atau dapat merupakan bagian dari neurofibromatosis atau penyakit Von Recklinghausen. Neurofibroma sering dikeluhkan karena alasan kosmetik atau adanya rasa nyeri terbakar dan gatal. Seorang laki-laki 56 tahun mengeluh benjolan di dada sebelah kiri sejak 43 tahun yang lalu. Benjolan awalnya muncul seperti jerawat yang bertambah besar secara lambat dan kadang terasa nyeri jika tersenggol baju sejak beberapa bulan terakhir. Riwayat keluarga ibu dan anak pasien terdapat benjolan yang sama. Pasien memiiki riwayat penyakit epilepsi. Pada pemeriksaan dermatologis didapatkan nodul sewarna kulit, bentuk bulat, batas tegas, diameter $3 \mathrm{~mm}-7,5 \mathrm{~mm}$ pada perabaan didapatkan konsistensi kenyal, mudah bergerak dan tidak terfiksasi dengan jaringan dibawahnya. Tidak didapatkan nodul lisch, freckles pada ketiak maupun tanda cafe-au lait. Pada pasien dilakukan tindakan bedah eksisi atas indikasi rasa tidak nyaman pada pasien. Pemeriksaan histopatologi jaringan hasil eksisi dengan pewarnaan HE dan imunohistokimia S100 menunjukkan gambaran sesuai dengan suatu neurofibroma. Neurofibroma dapat tumbuh secara invasif. Pada lesi yang mengganggu secara kosmetik sering dilakukan terapi pembedahan. Modalitas terapi pembedahan untuk menghilangkan neurofibroma bergantung pada tipe, lokasi, ukuran tumor. Modalitas terapi dapat dipilih bedah eksisi, bedah listrik maupun reseksi. Pada kasus ini dipilih modalitas terapi bedah eksisi pada neurofibroma. Hasil terapi setelah satu bulan menunjukkan hasil yang baik. Tidak tampak adanya gambaran skar hipertrofik
\end{abstract}

Kata kunci: eksisi, neurofibroma, imunohistokimia s100.

\section{EXCISION TREATMENT OF NEUROFIBROMA}

\begin{abstract}
Neurofibroma may be seen as a solitary nodule or as a part of neurofibromatosis or Von Recklinghausen disease. Patients often came for neurofibroma due to cosmetic reason or the presence of burning pain and itch that accompanied this disease. A fiftysix years old man complained an appearance of bump on his left chest since 43 years ago. At the beginning, the bump only appeared similar to acne but then it got bigger slowly over time and sometimes felt painful especially when being touched or rubbed with clothes since the last few months. Based on the family history, it was found that patient's mother and child also have similar bump. Patient also had a history of epilepsy. Dermatological examination revealed skincoloured nodule, round-shaped, well defined, with diameter 3-7.5 mm, rubbery and easy to move from palpation, not fixated to the underlying tissue. There was no lisch nodule, freckles on axillae, nor the café au lait sign. Patient was treated with surgical excision as indicated to overcome the uncomfortable sensation that was felt by the patient. Histopathological examination with HE colorization and immunohistochemical S100 examination of the excised tissue support neurofibroma. Neurofibroma can invasively grow. For cosmetically disruptive lesion, doctor often chose to do surgical treatment. This surgical modalities to remove neurofibroma are depend on the type, location, and size of the tumor. The treatment modalities that can be chosen: surgical excision, electrosurgery, or resection. In this case we chose surgical excision for neurofibroma. The result of the treatment after one month showed good progress. No appearance of hypertrophic scar.
\end{abstract}

Keywords: excision, immunohistochemical s100, neurofibroma.

* Departemen IImu Kesehatan Kulit dan Kelamin, Fakultas Kedokteran, Universitas Brawijaya-RSUD dr.

Saiful Anwar Malang

${ }^{* *}$ Departemen Patologi Anatomi, Fakultas Kedokteran Universitas Brawijaya

Email : yulianinneke@yahoo.co.id 


\section{Pendahuluan}

Neurofibroma adalah tumor jinak yang sering ditemui, tersusun dari sel neuromesenkim, termasuk sel Schwann, sel perineurial, sel fibroblast dan sel mast. Pertama kali dijelaskan oleh Smith pada tahun 1849 dan kemudian oleh von Recklinghausen pada tahun 1882. Insiden neurofibroma sama pada kedua jenis kelamin dan dapat terjadi pada semua usia. Neurofibroma pada kulit lebih sering terjadi daripada di jaringan lunak yang lebih dalam. Lesi yang terdapat di bawah kulit biasanya dalam distribusi aksial yang menunjukkan predileksi untuk batang tubuh dan kepala dibandingkan permukaan tubuh lainnya. Lesi soliter neurofibroma tidak terkait dengan tipe neurofibromatosis tipe 1 dan umum terjadi pada orang dewasa muda tanpa perbedaan jenis kelamin. ${ }^{1,2}$

Manifestasi klinis neurofibroma antara lain neurofibroma plexiformis, neurofibroma difus dan neurofibroma viseral. Neurofibroma soliter pada payudara jarang terjadi, bahkan pada wanita, yaitu hanya ada empat kasus. Neurofibroma soliter dapat tidak berkaitan dengan neurofibroma pada neurofibromatosis tipe 1 (penyakit von Recklinghausen).2,3,4 Neurofibroma dan schwannomas dilaporkan mewakili sekitar $10 \%$ sampai $12 \%$ dari semua neoplasma jinak jaringan lunak. ${ }^{5}$

Belum ada laporan perubahan cutaneus neurofibroma menjadi lesi yang ganas. Akan tetapi lesi neurofibroma sering dikeluhkan karena alasan kosmetik, sering terasa nyeri terbakar dan gatal terutama jika terkena pakaian. ${ }^{6}$ Banyak modalitas terapi untuk neurofibroma bergantung pada tipe, lokasi dan ukuran tumor serta preferensi dan pengalaman dari ahli bedah.

Neurofibroma dieksisi, atau yang biasa diartikan sebagai metode "cut out" dengan menggunakan scalpel atau dihancurkan dengan teknik bedah listrik. Tipe dan teknik yang digunakan bergantung dari ukuran, lokasi dan jumlah tumor yang diterapi. ${ }^{7}$ Pada laporan kasus ini akan dilaporkan cutaneus neurofibroma pada laki-laki berumur 56 tahun yang diterapi dengan bedah eksisi.

\section{Kasus}

Seorang laki-laki usia 56 tahun dari suku Jawa, mengeluhkan munculnya benjolan kecil di dada sejak sekitar 43 tahun yang lalu. Pada awalnya, benjolan muncul seperti jerawat tambah lama tambah besar. Benjolan dirasakan tidak gatal, tidak mudah berdarah, riwayat trauma sebelum benjolan muncul disangkal. Tidak ada riwayat keluar cairan seperti nanah dari benjolan. Benjolan sejak 7 tahun yang lalu dirasakan semakin membesar dan kadang terasa nyeri jika tersenggol baju. Muncul benjolan kecil yang sama di dada kiri dan punggung akan tetapi pasien tidak ingat secara pasti sejak kapan benjolan tersebut mulai muncul.

Tidak didapatkan bercak kecokelatan di badan, tidak didapatkan pandangan kabur atau dobel sejak kecil. Pasien memiliki riwayat kejang sejak 28 tahun yang lalu dan didiagnosis dengan epilepsi. Riwayat keluarga ibu pasien memiliki keluhan 2 benjolan yang hampir sama seperti pasien pada daerah paha dan wajah, juga tidak didapatkan bercak-bercak kecokelatan di sekitar badan dan ketiaknya. Putra pasien juga dikatakan memiliki benjolan yang sama seperti pasien.

Pada pemeriksaan fisik didapatkan keadaan umum baik, tampak sakit ringan. Pemeriksaan kepala dan leher tidak didapatkan anemia maupun ikterik pada konjuctiva, pemeriksaan jantung, paru, hepar tidak dilakukan. Tidak didapatkan edema pada ekstremitas. Tekanan darah 130/80, 


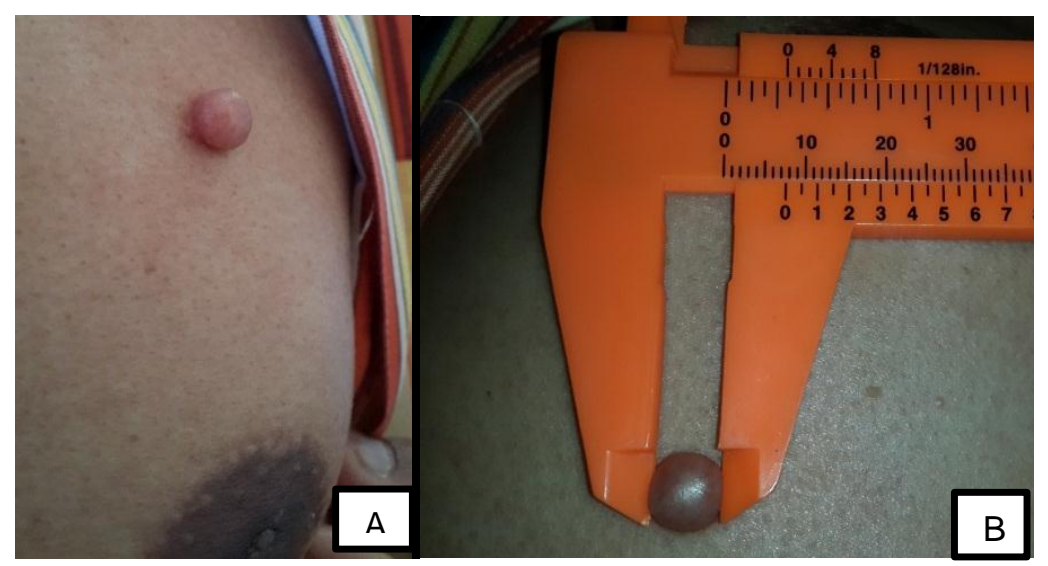

Gambar 1. (A) Nodul sewarna dengan kulit, bentuk bulat, batas tegas, dengan ukuran diameter 7,5 mm (B), pada palpasi didapatkan konsistensi kenyal, mudah bergerak dan tidak terfiksasi dengan jaringan dibawahnya, tidak nyeri.

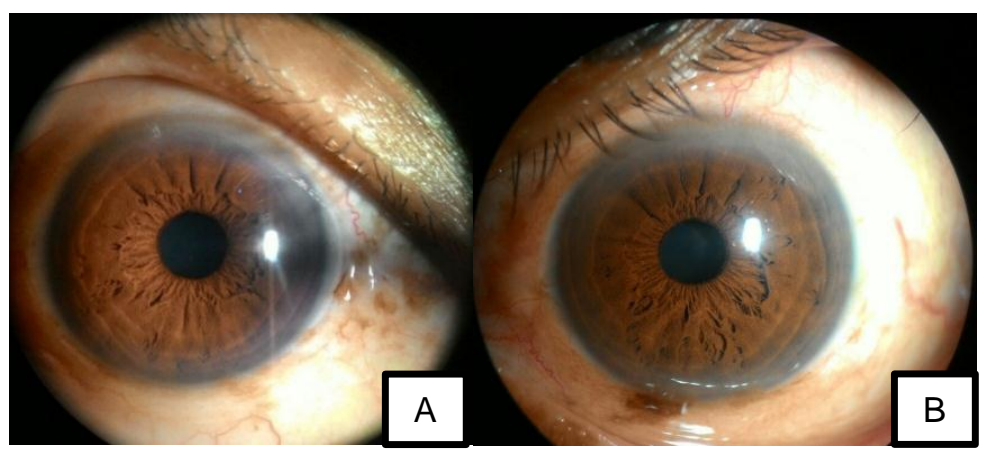

Gambar 2. Tidak didapatkan gambaran nodul lisch (A) Mata kanan, (B) Mata kiri

Pemeriksaan dermatologis pada
regiosupramamae sinistra didapatkan
batas tegas, dengan ukuran diameter 7,5
$\mathrm{~mm}$, pada palpasi didapatkan konsistensi
kenyal, mudah bergerak dan tidak terfiksasi
dengan jaringan dibawahnya, tidak nyeri. (Gambar 1).

Pada pemeriksaan mata tidak didapatkan gambaran nodul lisch (Gambar 2). Nodul lisch adalah suatu melanositik hamartoma pada daerah iris mata yang merupakan gambaran klinis yang ditemukan pada neurofibromatosis tipe 1. Dari anamnesis dan pemeriksaan fisik pasien didiagnosis neurofibroma dengan differential diagnosis dermatofibroma. Dilakukan bedah eksisi pada nodul setelah dilakukan KIE, informed consent, pemeriksaaan pra-operasi adanya nodul sewarna dengan kulit, bentuk bulat,

termasuk riwayat alergi terhadap obat bius, gangguan perdarahan, dan kondisi yang berhubungan dengan immunosupresi, dan adanya riwayat keloid pada pasien dan keluarga.

Prosedur pengambilan tumor dilakukan dengan simpel eksisi. Langkah awal dipersiapkan pasien dalam posisi tidur yang nyaman. Pertama dilakukan desinfeksi area operasi dengan povidone iodine. Kemudian ditutup menggunakan duk steril. Setelah itu dilakukan injeksi anastesi lokal dengan menggunakan pehacain dalam spuit $1 \mathrm{cc}$ pada daerah sekitar tumor (Gambar 3A). Dengan menggunakan blade nomor 11, dilakukan insisi linier pada permukaan atas 
tumor sampai terlihat kapsul jaringan tumor (Gambar 3B). Kemudian garis insisi diperlebar secara tumpul dengan hemostat dan dilakukan diseksi jaringan sekitarnya sehingga memudahkan untuk memisahkan tumor dengan jaringan disekitarnya (Gambar 3C). Setelah dilakukan diseksi dengan menggunakan hemostat, tumor berserta kapsulnya perlahan diangkat (Gambar 3D). Jaringan yang telah diangkat dimasukkan ke dalam formalin 10\% untuk dievaluasi di bagian Patologi Anatomi.

Sebelum dijahit dilakukan evaluasi ulang pada daerah lesi untuk melihat apakah masih ada jaringan yang tertinggal di dalam. Kemudian dilakukan pemotongan bagian kulit yang berlebih sebelum luka dijahit. Dengan menggunakan benang nonabsorbable 4.0 prolene, luka bekas pengangkatan tumor dijahit dengan menggunakan tekhnik simple interupted suture. Setelah dilakukan penjahitan maka luka bekas operasi dibersihkan dengan kassa steril yang telah dibasahi dengan normal salin (Gambar 3F). Kemudian luka dioles dengan salep gentamisin dan di tutup dengan kasa steril dan plester.
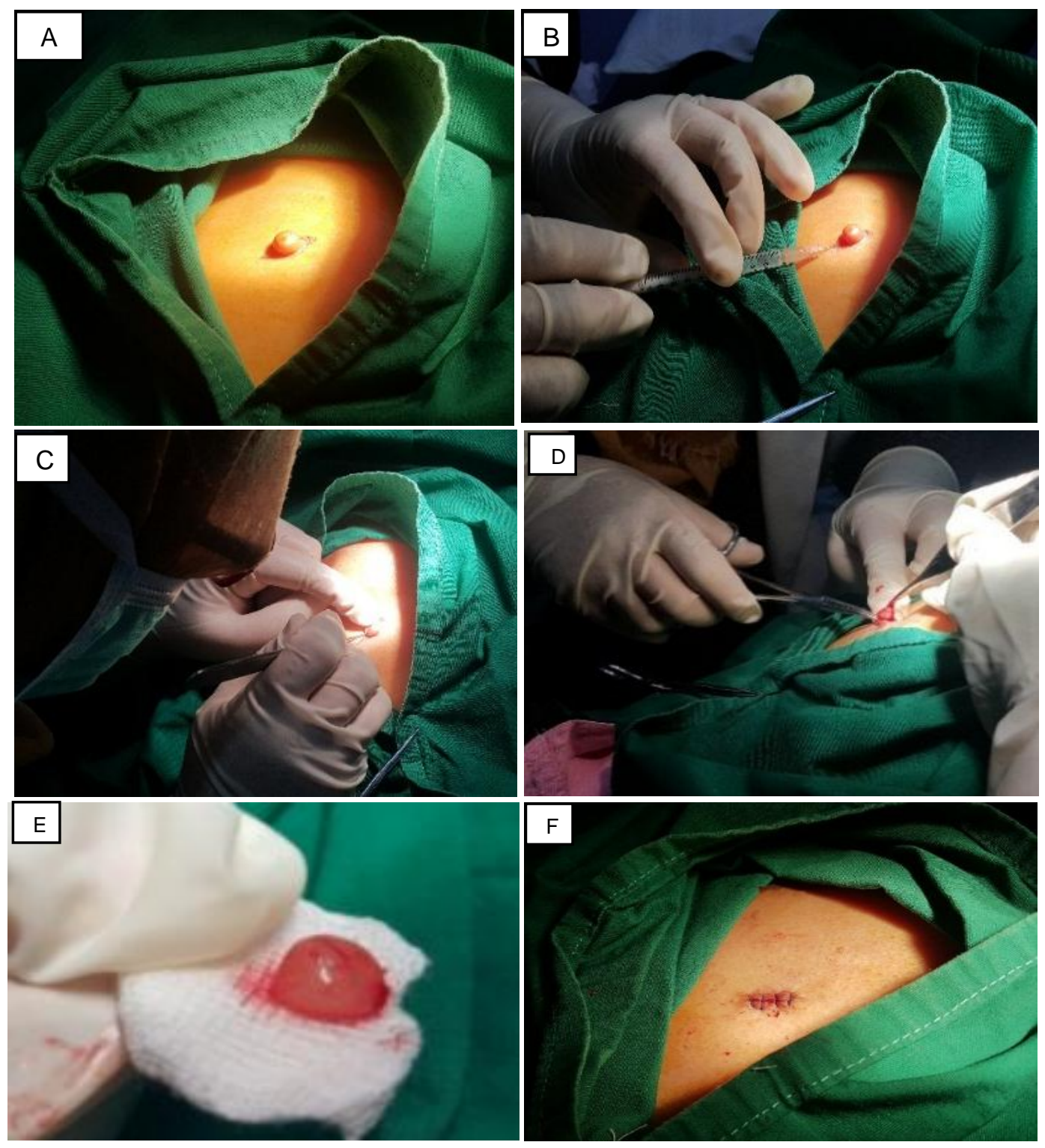
Gambar 3. Prosedur teknik operasi simpel eksisi neurofibroma (A-F)

Setelah dilakukan tindakan eksisi, pasien disarankan untuk mengoleskan gentamisin salep $2 \% \quad 2 \times$ sehari dan menutup luka dengan kassa steril. Pasien juga diberikan asam mefenamat $3 \times 500 \mathrm{mg}$. Hasil pemeriksaan histopatologi jaringan operasi didapatkan jaringan tanpa lapisan kulit terdiri dari proliferasi sel-sel spindel, bergelombang, dengan kromatin halus, tersusun diantara matrik kolagen. Gambaran tersebut mendukung gambaran neurofibroma (Gambar 4A). Pada pemeriksaan imunohistokimia $\mathbf{S} 100$ didapatkan hasil positif (Gambar 4B). Diagnosis neurofibroma ditegakkan berdasarkan anamnesis, pemeriksaan fisik dan pemeriksaan histopatologis.
Pada follow up 10 hari setelah operasi, jahitan diangkat seluruhnya. Pasien tidak mengeluh adanya nyeri, maupun bengkak pada luka jahitan. Pada inspeksi bekas luka menunjukkan tidak adanya tanda-tanda infeksi. Tampak adanya hipertrofi skar pada luka bekas operasi, kemudian dilakukan tindakan injeksi kortikosteroid intralesi selang satu minggu untuk mencegah pertumbuhan hipertrofik skar. Pasien juga disarankan untuk mengoleskan desoksimetason salep 0,25\% 2 kali sehari. Hasil follow up 1 bulan setelah tindakan operasi, pasien tidak mengeluhkan adanya nyeri atau bengkak pada bekas luka dan pada inspeksi bekas luka menunjukkan hasil penutupan luka yang baik, tidak ada tandatanda infeksi dan hipertrofik skar (Gambar 5).

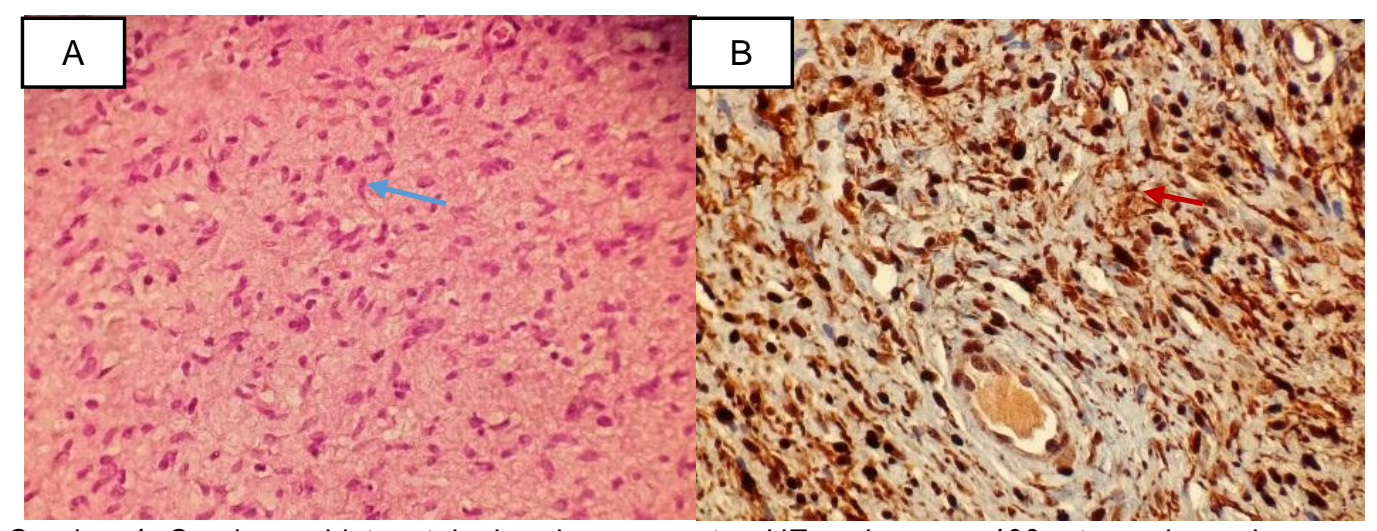

Gambar 4. Gambaran histopatologi pada pengecatan HE perbesaran 400x tampak gambaran sel spindel yang bergelombang menunjukkan suatu sel saraf $(\pi)$. Pada pemeriksaan imunohistokimia S100 didapatkan hasilk positif

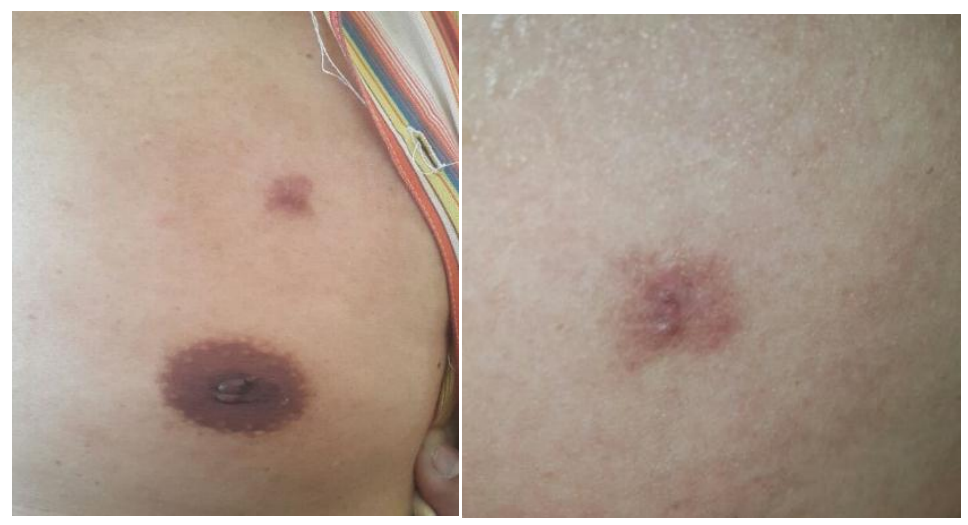


Gambar 5. Follow up 1 bulan pasca eksisi tampak penyembuhan luka yang baik, tidak didapatkan hipertrofik skar, terdapat patch eritematous sebagian hiperpigmentasi batas tegas

Pembahasan bentuk

Neurofibroma merupakan neoplasma yang paling umum terjadi pada sistem saraf perifer, yang berasal dari "sel schwann" dan fibroblas perineural dengan pertumbuhan yang lambat.8,9 Pada kasus didapatkan seorang laki-laki berumur 56 tahun dengan keluhan benjolan yang muncul sejak 43 tahun yang lalu tumbuh perlahan.

Neurofibroma dapat diklasifikasikan menurut lokasi anatomi antara lain cutaneous, subkutan, intraneural, dan plexiform. Neurofibroma plexiform adalah massa tumor kongenital yang melibatkan batang saraf dan sering meluas ke kulit, sedangkan cutaneus neurofibroma tidak terdeteksi saat lahir dan biasanya muncul selama masa remaja. Sel tumor pada neurofibroma tidak pernah mengalami perubahan ganas dan diameter tumor biasanya bervariasi dari milimeter sampai 2 $\mathrm{cm}$, jarang melebihi $3 \mathrm{~cm} .{ }^{10}$

Pada banyak kasus yang dilaporkan neurofibroma sering muncul sebagai lesi yang tidak nyeri, terisolasi pada kulit dan seringnya muncul tidak lebih besar dari diameter $2 \mathrm{~cm}$. Secara klinis neurofibroma tumbuh lambat tanpa ada gejala penyebab sehingga diagnosis dan penatalaksanaan terlambat.11

Pada kasus didapatkan nodul multiple sewarna dengan kulit, bentuk bulat, batas tegas, dengan ukuran diameter $3-7,5 \mathrm{~mm}$. Pada palpasi didapatkan konsistensi kenyal, mudah bergerak dan tidak terfiksasi dengan jaringan di bawahnya. Pasien kadang merasa benjolan terasa nyeri jika terkena pakaian. Cutaneus neurofibroma tampak sebagai benjolan sampai pedunculated, sewarna kulit, pada perabaan lembut atau padat, biasanya asimtomatik dapat disertai ireguler

(B). dengan rasa gatal. Neurofibroma subkutan biasanya lebih besar dari pada lesi dermal dan terdiri dari pembengkakan fusiform yang melibatkan saraf yang lebih besar. ${ }^{12}$

Neurofibroma sering terjadi sebagai lesi soliter dan sering terjadi pada populasi umum. Neurofibroma tipe 1 memiliki prevalensi 1:4.000. Sedangkan angka prevalesi neurofibroma sendiri belum ada literatur yang menyebutkannya. Pada neurofibroma terjadi hiperplasia dari semua elemen saraf.

Neurofibroma dapat dilihat sebagai lesi sporadis jika berhubungan dengan neurofibromatosis tipe 1. Gen untuk neurofibromatosis tipe 1 terletak pada lengan panjang kromosom 17q11.2. Salah satu fungsi protein neurofibromatosis tipe 1 , neurofibromin adalah regulasi dari ras onkogen. Meskipun telah dibuktikan bahwa neurofibromatosis tipe 1 pada tikus dapat menyebabkan perkembangan neurofibroma, akan tetapi pengaruh dari ras tidak selalu konsisten, sehingga efek stroma atau faktor genetika lainnya juga memiliki pengaruh pada terjadinya neurofibroma. ${ }^{12}$ Pada laporan kasus ini, ibu pasien dan putra pasien juga memiliki keluhan benjolan yang sama. Hal tersebut menunjukkan terdapat pegaruh genetik pada neurofibroma.

Neurofibroma menunjukkan heterogenitas selular yang luas yang terdiri dari hiperproliferasi sel Schwann, fibroblas, sel mast dan sel perineural. Sel Schwann dikatakan sel yang menginisiasi terjadinya neurofibroma dan hanya pada sel ini gen neurofibromatosis tipe 1 dapat menjadi inaktif secara biallel. Sel Schwann juga merupakan target dari berbagai faktor pertumbuhan yang diketahui dapat menstimulasi formasi dan pertumbuhan neurofibroma, akan tetepi masih belum 
diketahui secara pasti sel yang pasti diturunkan. ${ }^{13}$

Cutaneus neurofibroma berasal dari sel prekursor kulit (skin-derived precursor cells/SKPs) dan sel ini dapat dipengaruhi oleh hormon sehingga kebanyakan tumor ini muncul pada saat pubertas. Selain itu, peningkatan ukuran tumor dan jumlahnya dapat meningkat saat hamil, dan beberapa bukti menunjukkan berkurangnya ukuran tumor setelah melahirkan. ${ }^{14}$ Hampir seluruh tumor saraf perifer muncul kongenital dan diduga tumor ini dipicu oleh mutasi somatik. ${ }^{15}$ Sema4F yang merupakan protein transmembran diekspresikan ekstraselular mengalami regulasi yang menurun pada neurofibroma dan dikatakan dapat memicu secara tidak langsung proliferasi sel Schwann. Sel Schwann yang berproliferasi lebih responsif terhadap sinyal lingkungan kemungkinan disebabkan oleh hambatan penempelan kembali aksonal. Oleh karena itu, interaksi normal aksonal sel Schwann yang terganggu menyebabkan perkembangan neuro-fibroma. ${ }^{13}$

Gambaran histopatologi neurofibromas menunjukkan tumor campuran yang terdiri dari sel dengan karakteristik diferensiasi yang berbeda. Pengecatan histologis sederhana, serta imunohistokimia dengan berbagai biomarker dan mikroskop elektron, menunjukkan bukti keterlibatan sel Schwann, sel perineurial, dan fibroblast. ${ }^{16,17}$ Neurofibroma juga mengandung banyak sel mast dan proses aksonal, yang semuanya tertanam dalam matriks ekstraselular kolagen yang melimpah.

Neurofibroma kulit tampak sebagai nodul batas tegas tidak terenkapsulasi. ${ }^{12}$ Pada pemeriksaan histopatologi hasil eksisi tumor didapatkan jaringan tanpa epitel pelapis terdiri dari proliferasi sel-sel spindel, bergelombang, kromatin halus, tersusun di antara matriks kolagen. Gambaran tersebut mendukung gambaran neurofibroma dan diperlukan konfirmasi pemeriksaan imunohistokimia S100. Pada pemeriksaan imunohistokimia S100 didapatkan hasil positif sehingga benjolan tersebut memang merupakan neurofibroma

Gambaran khas dari tumor selubung saraf perifer adalah adanya proliferasi neoplastic dengan diferensiasi sel Schwann. Sel Schwann merupakan komponen utama sel neoplasia pada neurofibroma, secara sitologi ditandai dengan bentuk inti yang bergelombang dan ekspresi S-100. Neurofibroma juga melibatkan komponen sel non-neoplastik saraf perifer seperti akson, sel perineural, fibroblas dan berbagai elemen inflamasi seperti sel mast dan limfosit. Selain itu, pada populasi CD34 sel yang tidak berinti juga memberi gambaran positif. ${ }^{10}$

Neurofibroma kulit dapat merupakan ciri khas neurofibromatosis tipe 1. Neurofibroma terdiri dari beberapa jenis sel yang diyakini berasal dari saraf kecil di kulit. ${ }^{8}$ Setengah dari pasien dengan neurofibromatosis tipe 1 mewarisi mutasi neurofibromatosis tipe 1 dari orang tua dan separuh lainnya disebabkan oleh mutasi neurofibromatosis tipe 1 de novo. Gambaran klinis dan tingkat keparahan neurofibromatosis tipe 1 sangat bervariasi. ${ }^{18}$ Neurofibromatosis tipe 1 disebabkan oleh mutasi pada gen neurofibromatosis tipe 1 yang mengkodekan protein neurofibromin supresor tumor.

Pada pasien telah dilakukan pemeriksaan baik dari anamnesia maupun pemeriksaan fisik, namun masih belum mendukung diagnosis neurofibromatosis 1 . Neurofibroma memiliki gambaran histologi jinak namun bisa kambuh secara lokal. Pada literatur angka kekambuhan untuk neurofibroma plexiform $44 \%$ terutama pada anakanak. Guha dkk., melaporkan tingkat kekambuhan untuk schwannoma dan neurofibroma masing-masing adalah 5,3\% dan $8,2 \%{ }^{19,20}$

Neurofibroma dapat tumbuh secara invasif dalam jumlah yang banyak, ataupun 
hanya ditemukan soliter. Neurofibroma sering dikeluhkan karena alasan kosmetik, terasa nyeri terbakar dan gatal terutama jika terkena pakaian. ${ }^{6} \mathrm{Hal}$ tersebut yang menyebabkan beberapa orang mencari pengobatan untuk menghilangkan lesi neurofibroma. Terapi pembedahan adalah metode yang paling efektif untuk mengendalikan atau menghilangkan lesi neurofibroma soliter. Pada neurofibroma soliter atau dengan jumlah yang sedikit antara 1-15 sering dipilih tindakan bedah eksisi sederhana dengan menggunakan skalpel. Sedangkan pada lesi neurofibroma yang lebih banyak sering dipilih tindakan dengan bedah listrik yaitu elektrodesikasi atau elektrofulgurasi atau kombinasi antara bedah eksisi dengan skalpel dan elektrodesikasi (bedah listrik). ${ }^{7}$

Untuk neurofibroma plexiformis terapi reseksi saat ini merupakan pilihan pengobatan terbaik walaupun dilaporkan lesi sering kambuh kembali setelah tindakan reseksi. Kekambuhan lebih sering dikaitkan dengan usia pasien muda, reseksi tumor yang tidak lengkap, atau lokasi tumor nonekstremitas. ${ }^{12}$ Prosedur pengelolaan bedah ditetapkan berdasarkan anatomi tumor, lokasi tumor dan komunikasi komprehensif dengan pasien. ${ }^{19,20}$

Pada pasien ini dilakukan tindakan bedah eksisi simpel untuk mengangkat satu lesi neurofibroma atas indikasi didapatkan keluhan rasa tidak nyaman dan nyeri. Tindakan follow up setelah satu bulan menunjukkan hasil yang baik, tidak didapatkan adanya hipertrofik skar serta tidak didapatkan rekurensi setelah follow up satu tahun.

\section{Daftar Pustaka}

1. Lee YB, Lee Jl, Park HJ, Cho BK. Solitary Neurofibromas: Does An Uncommon Site Exist?. Annals of Dermatology. 2012; 24(1):101.
2. Jeyaretna DS, Oriolowo A, Smith ME, Watkins RM. Solitary Neurofibroma In The Male Breast. World Journal of Surgical Oncology. 2007; 27:5(1):23.

3. Thompson S, Kaplan SS, Poppiti RJ, Collado-Mesa F, Rabinovich K. Solitary Neurofibroma of The Breast. Radiology Case Reports. 2012; 31:7(4):462.

4. Gutmann DH. Tumorigenesis in Neurofibromatosis: New Insights and Potential Therapies. Trends in Molecular Medicine. 2001; 7(4):157-62.

5. Levi AD, Ross AL, Cuartas E, Qadir R, Temple HT. The Surgical Management of Symptomatic Peripheral Nerve Sheath Tumors. Neurosurgery. 2010; 66(4):833-40.

6. Ferner RE, Huson SM, Thomas N, Moss C, Willshaw $H$, Evans DG, Upadhyaya M, Towers R, Gleeson M, Steiger C, Kirby A. Guidelines for the Diagnosis and Management of Individuals with Neurofibromatosis 1. Journal of Medical Genetics. 2007; 44(2):81-8.

7. Pannosian A, Hurberg W. Removing Neurofibroma. 2017. (Online). www.nfmidwest.org. Diakses 13 September 2017.

8. Greinwald J, Derkay CS, Schechter GL. Management of Massive Head and Neck Neurofibromas in Children. Am J Otolaryngol. 1996; 17:136-42.

9. Damm DD, Bouquot JE, Neville BW, Allen C. Oral \& Maxillofacial Pathology. $3^{\text {rd }}$ Edition. St.louis: Sauders Elservier. 2009. p. 528,530.

10. Jouhilahti EM, Peltonen $S$, Callens $T$, Jokinen E, Heape AM, Messiaen L, Peltonen J. The Development of Cutaneous Neurofibromas. The American Journal of Pathology. 2011; 178(2):500-5.

11. Marocchio LS, Oliveira DT, Pereira MC, Soares CT, Fleury RN. Sporadic and Multiple Neurofibromas in the Head and 
Neck Region: A Retrospective Study Of 33 Years. Clin Oral Invest. 2007; 11:165-169.

12. White L, Levy RM, \& Alam M. Neoplasias and Hyperplasias of Muscular and Neural Origin. In: Wolff $\mathrm{K}$, Goldsmith LA Katz SI, Gilchrest BA, Paller AS, Leffell DJ. Fitzpatricks Dermatology in General Medicine. McGraw-Hill editors. 8th Edition. New York: McGraw-Hill. 2010; p. 1470.

13. Spyk SLV, Thomas N, Cooper DN and Upadhyaya M. Neurofibromatosis Type 1-Associated Tumours: Their Somatic Mutational Spectrum and Pathogenesis. Human Genomics. 2011; 5(6):623-690.

14. Roth $T$, Ramamurthy $P$, Muir D, Wallace $M$. et al. Influence of Hormones and Hormone Metabolites on The Growth of Schwann Cells Derived from Embryonic Stem Cells and on Tumor Cell Lines Expressing Variable Levels of Neurofibromin. Dev Dyn. 2008; 237:513-524.

15. Wu J, Williams J, Rizvi T, Kordich J. et al. Plexiform and Dermal Neurofibromas and Pigmentation are Caused by Neurofibromatosis Tipe 1 Loss in Desert Hedgehog-Expressing Cells. Cancer Cell . 2008; 13:105-116.

16. Lassmann $\mathrm{H}$, Jurecka $W$, Lassmann $G$, Gebhart W, Matras H, Watzek G.
Different Types of Benign Nerve Sheath Tumors. Light Microscopy, Electron Microscopy and Autoradiography. Virchows Arch A Pathol Anat Histopathol. 1977; 375:197-210.

17. Pummi K, Aho H, Laato M, Peltonen J, Peltonen S. Tight Junction Proteins and Perineurial Cells in Neurofibromas. $J$ Histochem Cytochem. 2006; 54:53-61.

18. Jouhilahti EM, Peltonen S, Heape AM, Peltonen J. The Pathoetiology of Neurofibromatosis 1. The American Journal of Pathology. 2011; 178(5):1932-9.

19. Yuan SM, Cui L, Guo Y, Wang J, Hu $X B$, Jiang $H Q$, Hong ZJ. Surgical Management of Giant Neurofibroma in Soft Tissue: A Single-Center Retrospective Analysis. International Journal of Clinical and Experimental Medicine. 2015; 8(4):5245.

20. Guha D, Davidson B, Nadi M, Alotaibi NM, Fehlings MG, Gentili $F$, Valiante TA, Tator $\mathrm{CH}$, Tymianski M, Guha A, Zadeh G. Management of Peripheral Nerve Sheath Tumors: 17 Years Of Experience at Toronto Western Hospital. Journal of Neurosurgery. 2017; 7:1-9. 